\title{
Student Views on the 4MAT Teaching Model Application in the Two Dimensional Art Studio Classes in the Fine Arts High School ${ }^{1}$
}

\author{
Handan BÜLBÜL \\ Giresun University, Turkey \\ handanbulbu105@hotmail.com
}

\author{
Vedat ÖZSOY \\ TOBB Economy and Technology University, Turkey \\ vozsoy@etu.edu.tr
}

\begin{abstract}
The aim of this study is to determine the effect of the 4MAT teaching model on students in fine arts high school two dimensional art studio classes. This study was designed as a model case sample and it was conducted in a two dimensional art studio class in a fine arts high school. The study case consisted of eight 9th graders and after 14-week of practice process, the students perceptions and reactions about the model were assessed. The data were collected by the researchers by a semi-structured interview and an openended questionnaire after the interview. Content analysis method was used to analyze the data. The students stated that the 4MAT teaching model had a positive effect on them and they would like their classes in the following years if it was organized according to this model.
\end{abstract}

Key Words: Fine arts high school, Two dimensional art studio class, 4MAT teaching model.

\footnotetext{
${ }^{1}$ This article was prepared by using the data presented in the dissertation thesis of Handan Bülbül (Ass. Prof. Dr). The thesis was completed in 2013 with the help of her supervisor Prof. Dr. Vedat Özsoy at Gazi Universitiy, Education Science Institute.
} 


\section{Introduction}

The fact that student-centered teaching models are not focused on what to teach but how to teach has accelerated the studies on learner characteristics and the concept of learning styles has been shaped in this process. Learning styles which are accepted as the all choices of the learner during learning process have become a topic of research for many psychologist and pedagogue since 1940s (Erden \& Altun, 2006). Though learning styles accepted as one of the most important indicators about the needs, motivation, attitude, and expectation in the learning environment are not the only reason for learning to occur at different stages, they are accepted as one of the most important components of the teaching learning process (Ekici, 2003; O'Banion, 1997). The principles of studies including learning styles depend on Carl Jung's "personality types theory” (Ekici, 2003; Keefe \& Ferrell, 1990). However, the concept has gained a significant importance with Kolb's "experimental learning theory" which is based on learning theories of Dewey, Lewin, and Piaget (Açıkgöz Ün, 2005). According to experimental learning theory, learning is a four-step process. This process proceeds in circles and makes the learner gain new experiences, and the gained experiences lead the learner in the next learning processes (Kolb, 1984).

In spite of the fact that it is affected from many learning styles, the 4MAT (4 Mode Applications Techniques) is theoretically based on Kolb's experimental learning theory but essentially based on teaching styles developed by McCarty. McCarty (2000), based on Kolb, states that different learning styles are formed by the differences that occur during the perception and processing of information. As in Kolb's learning cycle which is based on experimental learning theory, in the 4MAT each quarter is categorized as imaginative learners

(Type 1), analytic learners (Type 2), common sense learners (Type 3) and dynamic learners (Type 4) depending on learning styles. McCarthy learning styles are shown in Figure 1. 


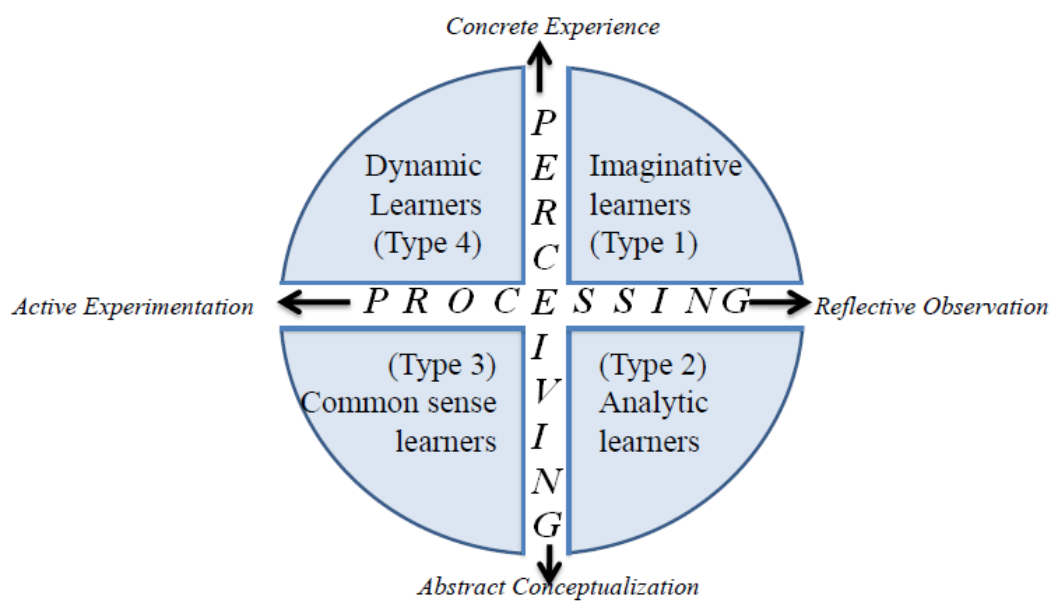

Figure 1. McCarthy Learning Styles

The vertical axis of the cycle shows the perception the information and the horizontal axis shows the organization of information. The perception of information dimension is consisted of a movement from tangible experience to abstract conceptualizing and the organization of information dimension is consisted of a movement from reflective observation to active experience. According to McCarthy $(1982,1997,2000)$, all students take place in a quarter of the cycle. In a class there are students from all four learning styles, therefore a suitable teaching should be presented to each student. The 4MAT learning cycle is more important than any part of the cycle. Because each quarter presents a suitable learning environment to the students in that quarter while it also helps the students to orientate themselves to other learning styles in other quarters. Therefore a learning environment in which the students learn to make use of others' learning styles is created.

The studies of Dax, Gall, Spinger and Deutsch showed difference between the functions of right and left hemispheres of the brain (Duman, 2007). Findings of these studies have indicated that the left hemisphere of the brain organizes logical and analytical thoughts whereas the right hemisphere functions about intuitional and integrated ones (San, 2004; 
Özsoy, 2003; Caine \& Caine, 2002). These findings have helped the case that learning styles are different from one another to be accepted (Denison \& Kirk, 1990).

These studies about the dominance of brain hemispheres have contributed to develop the 4MAT teaching cycle. Therefore, the 4MAT learning cycle was designed to have 4 learning styles and in each quarter suitable teaching techniques were used depending on the dominance of right or left hemisphere. This cycle is complete in 8 steps (McCarthy, 1997). 4MAT teaching model is shown in Figure 2.

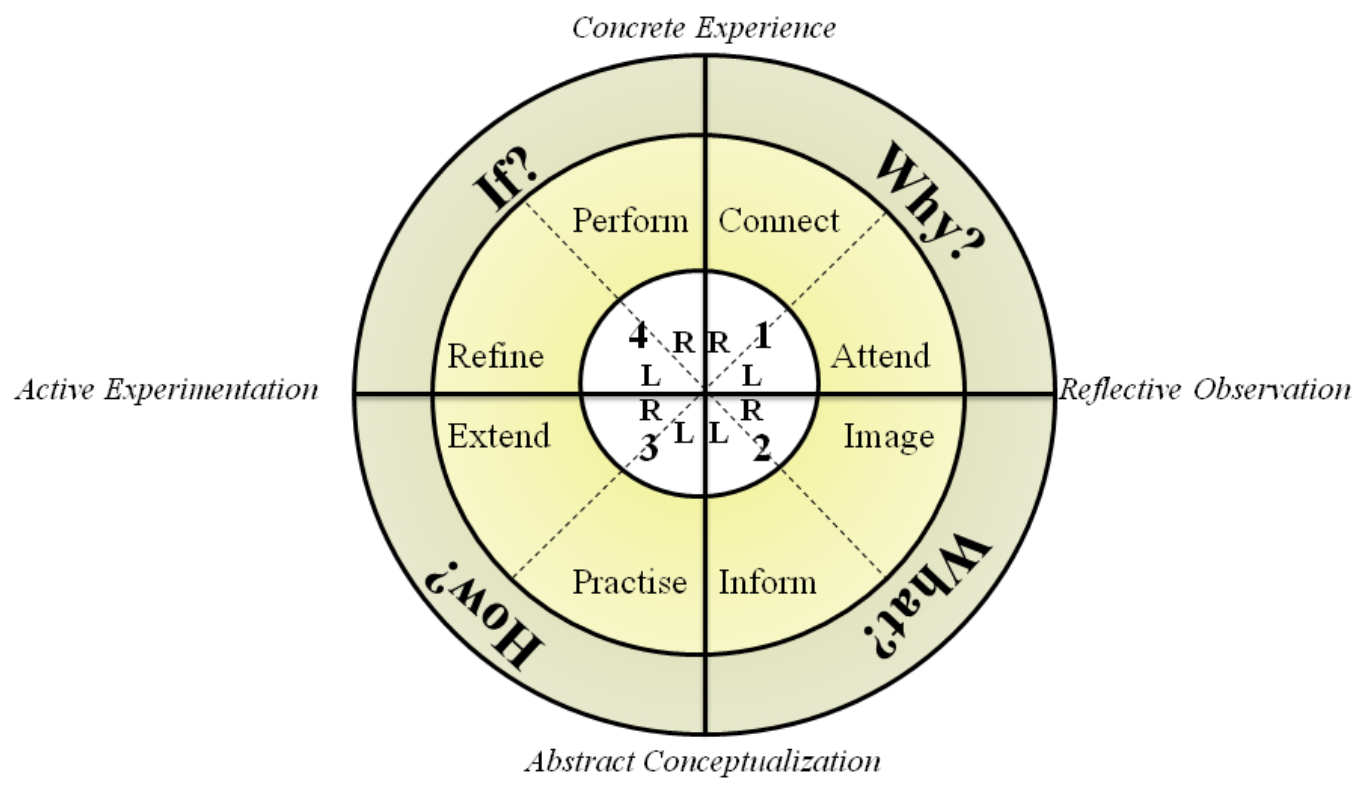

Figure 2. The 4MAT Teaching Model

In the first step of the 4MAT teaching model, teacher presents an experience to the students. The students are put into groups and each group receives an experience sheet (McCarthy, 1987). The most significant behavior of the teacher at this level is to correlate students with the learned concept. Therefore the concept is associated with everyday life. In the second step, analysis should be made based on the experience presented by the teacher. A discussion is started among students about what they have understood about the tangible experience presented in the first step. In this way all students are interested in what other students have 
perceived. The students are allowed to reflect similar experiences by seeing, sharing and discussing. In the third step, before the students are presented with expert information, they should have their own experiences. Therefore, they are made to understand, visualize and envisage the concept (McCarthy, 2000). In the fourth step, students' ability to create information and concept is developed. The teacher presents the subject to the students and defines the concepts by using different resources such as CDs. In the fifth step where the students begin to be active, the learned concepts and formulas are implemented, reinforced and problems in which the formulas are used are solved (McCarthy, 1987). In the sixth step, the students experience the information that they have learned before. In this step where innovation begins, the students gain skills of how to use formulas, what they can do in as part of the defined concepts and how to interpret the acquired information (McCarthy, 2000). In the seventh step, student activities are analyzed to create a step aimed at future learning. Leading students to do a project or a performance task are the techniques that are used in this step (McCarthy and McCarthy, 2006). The eighth step where the students perform themselves and share what they do with others is where practice and experience are integrated. This step, which is different from the others, is the one where students share their practices, realize the differences in their creativities and that everyone's skill is important (McCarthy, 1987).

The 4MAT teaching model that is designed according to the brain hemisphere dominance with four basic learning styles has been the source for researches in various disciplines such as geometry, mathematics, microbiology, history, geography, science, music,English and compiter engineering education. Bowers (1987), Wilkerson \& White (1988), Appell (1991), Paxcia-Bibbins (1993), Ursin (1995), Jackson (2001), Demirkaya (2003), Peker (2003), Mutlu (2004), Dikkartın, (2006), Tatar, (2006), Öztürk (2007) and Ergin (2011) had concluded in their studies that model had positive effects on students' attitudes. There are some studies 
depending on the 4MAT teaching model in various disciplines but there is only one study (Stinespring \& Kennedy, 1993) in visual arts education field. In fact, visual arts education is a field in which utmost attention should be paid to the student's individual characteristics. In addition, it is found that there isn't any study depending on the 4MAT teaching model or other learning styles in fine arts high schools that are art weighted.

Buyurgan (2007) states that fine arts high schools create a functional link in the chain of art education and suggests that researches should be carried out focusing on the teaching and learning program including above mentioned high schools. However, there are very few studies concerning teaching painting in these schools. According to the results of a study (Yavuz, 2010) which was carried out in fine arts and sports high schools' two dimensional art studio classes, it was concluded that the teaching-learning process of the class should be enriched with examples from life, and the teaching activities should be re-organized so as to encourage students to question their artistic works and canalize them to explore new subjects.

Kırışoğlu (2005) states that intensive information and experience are not enough in every field and he adds that especially in visual arts teaching, traditional teaching methods and techniques are not adequate. He underlines that semi controlled teaching models which are self-regulating, developing with inner dynamics are needed. According to Buyurgan (2000) the art education in fine art high schools are not intended to make students try, think, and research and in order to resolve this negative aspect, educational models that are based on students' individual characteristics are seen as a choice. In this respect, it is foreseen that 4MAT teaching model which is designed suitable for both hemisphere dominance and based on learning styles is a suitable teaching model in two dimensional art studio classes in fine arts high schools. 


\section{Purpose of the Study}

The purpose of this study is to determine students' views about activities arranged according to the 4MAT teaching model in two dimensional art studio classes in $9^{\text {th }}$ grade of a fine arts high school. Based on this purpose, below mentioned questions were asked:

\section{Research Questions}

1) What are the students' views about the student responsibilities in the activities?

2) With what gains do the students think the activity process will provide them?

3) What is the emotional response of the students about student assignments?

4) What do the students feel in the activity environment?

\section{Method}

\section{Research Model}

This research is a qualitative research figured as an activity research. An activity research is a systematic approach in which the researcher himself or with another researcher do the research and it is conducted to gain information about the quality of the teaching and how the students can learn better. Therefore, new points of views can be developed to contribute to teaching and improve the teaching quality (Mills, 2007; Johnson, 2005).

\section{Participants}

Model case sample, one of the purposeful sampling methods, was used to determine the study group. This is a sampling method that allows thoroughly study the cases with rich information and that emerge in qualitative research environment. Model case sample is a sampling method 
that takes part in purposeful sampling method and used to introduce a new method or an innovation (Yıldırım \& Şimşek, 2006). The study group of this study includes 8 students studying at $9^{\text {th }}$ grade in a fine arts high school.

\section{Research Process}

The research period consisted of 14 weeks and the activities of 4 units. Each event is organized according to the eight steps of the 4MAT teaching model. Plans prepared for each activity were applied with the consensus of the researcher, expert of the domain and a qualified 4MAT teaching model expert. Researchers sticked to the attainments of the unit involving the activities and video recording control lists which contain the deities of the teachers and students according to the eight steps of the 4MAT teaching model were prepared. "Yes", "Partly" and "No" sections were added to the list so as to determine how the activities were carried out according to each step of the teaching model. Observers involved in the validity committee had examined each video recording and marked the duties performed by the teachers and the students. When there were some items including "partly" or "no" answers for teacher/student duties and a disagreement among the observers all the details were discussed by the committee including the strategies that will make the next activity more appropriate to the 4MAT teaching model. This process was repeated after each event, and at the end of the macro analysis and after the third activity, it was identified that the model had proceeded through all steps. The research process can be seen in figure 3 . 


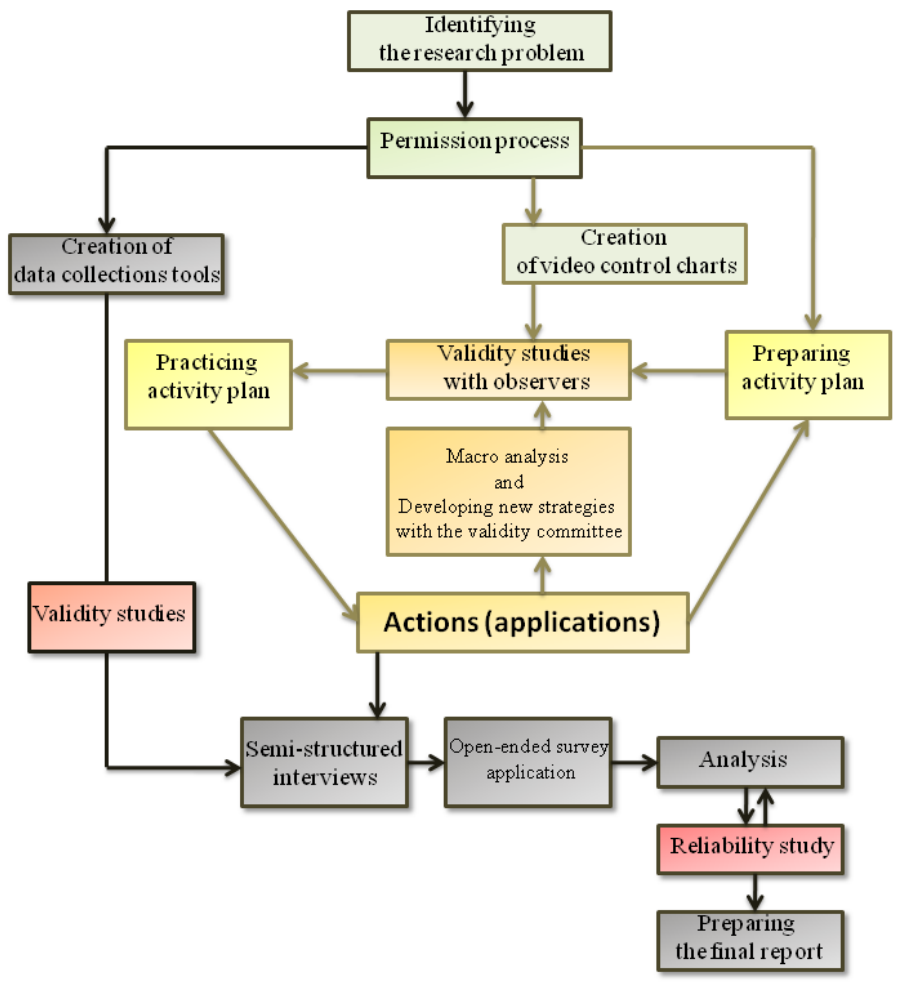

Figure 3. The Research Process

After completing the actions within the framework of the study, interviews and open ended surveys were carried out. Thus, students' perceptions and responses were tried to determine towards the teaching model.

\section{Data Collection Tools}

Interview technique and document analysis were used to collect data in the study. Interview is an effective tool for data collection in order to determine the perception, response and experience of the participant. Interviews can be done individually as well as in the form of focus group discussions (Yıldırım \& Şimşek, 2006). They can be categorized as structured and semi-structured (Kuş, 2003). For the interview, a semi-structured interview form including 10 questions was developed by the researcher. Then the form was designed as an open ended questionnaire. 
In order to ensure internal and external validity of the questions in the semi-structured interview, two experts analyzed the interview form. A pilot interview was conducted with one of the students from the study group and after it was determined that the questions were clear and they could provide the necessary data, validity of the questions was ensured.

Interview process: In was conducted in 3 sessions on the same day and the first session lasted $40^{\prime}: 29^{\prime \prime}$, the second one $41^{\prime}: 30^{\prime}$ ' the last one $35^{\prime}: 59^{\prime \prime}$ ' and totally $118^{\prime}: 58^{\prime \prime}$ of tape was recorded.

In action research, it is necessary to have a plan and a calendar before the data collection process. However, plans or data collection tools can change according to the new situations (Johnson 2005). In this research, initially it was decided to take the advantage of only interviews. However, during the interview process, it was observed that some students got bored and some of them had difficulty in expressing themselves in a social group. Because of the concerns about not getting profound information through interviews, eight copies of the interview form were printed and converted into open-ended questionnaire then distributed to each student. Therefore written student views were also gathered.

\section{Data Analysis}

Content analysis technique was used to analyze the data. Before starting content analysis, the data was separated into significant groups (Stringer, 2008) and coded based on analysis themes (Bilgin, 2006). Data collected from the interviews were transferred into computer forms and numbered. They were combined with the data collected from open-ended questionnaires and schema themes were created. The interview and open ended questionnaires were converted into themes and draft theme lists were prepared. At this stage, within the scope of reliability, the researcher and an expert read the data obtained from interviews and open ended questionnaire at the same time and they tried to reach a consensus on the themes 
prepared as a draft. Following the finalization of the themes the first researcher made the coding by reading the data set. First, codes of similar nature were gathered under the related sub themes and then codes were associated with the sub-themes and finally temporary code list was formed. After this procedure, first expert had read the data set according to the prepared code list, and examined the code list prepared by the researcher and mentioned the points that he/she disagreed. Agreed codes and themes were left untouched and after mutual discussion about disagreed points, the list was finalized. In the next stage, the data obtained from the data set were arranged by gathering the data under the related sub-themes and codes. In this process, to control any possible error in arranging the data, besides the first researcher and the first expert, second expert's opinion was asked in order to create a different perspective; consequently, second reliability study was made. By the help of the feedback from the second expert, analysis process was completed and obtained findings were associated with the sub objectives of the study, and they were defined and interpreted by exemplifying.

\section{Findings and Comments}

\section{a) Student responsibilities in the activities}

The theme "student responsibilities in the activities" consisted of sub themes as "responsibilities in the studio" and "responsibilities outside the studio". The codes about these sub themes are shown in Figure 4.

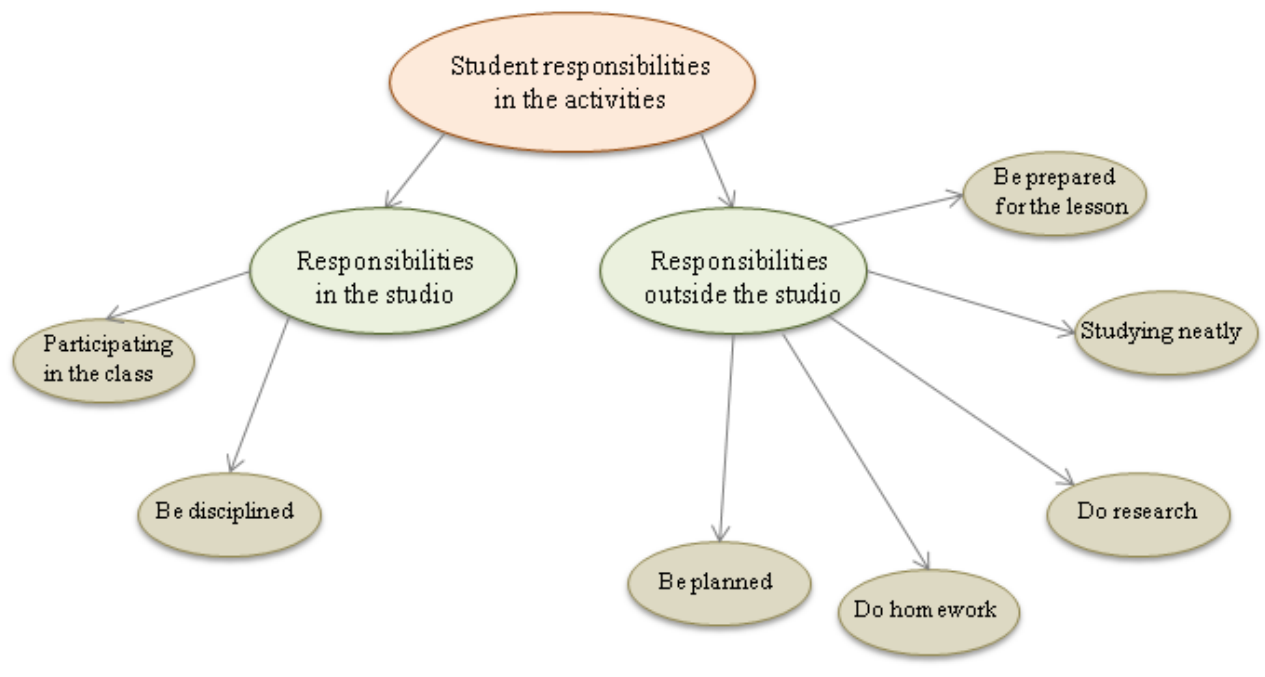


Figure 4. Student Responsibilities in the Activities

"Responsibilities in the studio" has two codes: "participating in the class" and "be disciplined". Nehir, Kayhan, and Seval among the students stated that discussing the questions about learning story presented in the $1^{\text {st }}$ step of 4MAT teaching model helped them participate in the lesson. Caner and Yekta said that the applied learning model created a class discipline.

"Responsibilities outside the studio" has codes as "be planned", "do homework", "do research", "studying neatly" and "be prepared for the lesson". Being planned outside the studio was stated as "we had to be neat" by Nehir, "we learned not to put off tomorrow what we can today" by Kayhan. They indicated that they had to do their work outside the studio in a planned way. Ezgi, Seval, Yekta, and Caner stated that the project homework lead them to be planned.

Nehir, Engin, and Kayhan emphasized that the homework laid a burden on students outside the studio. About the way the lesson was taught; Ezgi stated that it encouraged her to study more neatly, Yekta said he had the responsibility to do some research before the lesson and Seval stated that it made her get ready for the lesson by revising the previous lessons.

In 8-step the 4MAT learning model, student assignments and responsibilities change on each step. In order to move onto the next step, students had to complete their assignments and responsibilities on the existing step. It was concluded that this applied model gave students responsibilities both in the studio and outside the studio. 


\section{b) The gains of the Activities}

The theme "the gains of the activities" has three sub themes: "gains related to learning", "social gains" and "the gains acquired". Sub themes and the codes related to these themes are shown in Figure 5.

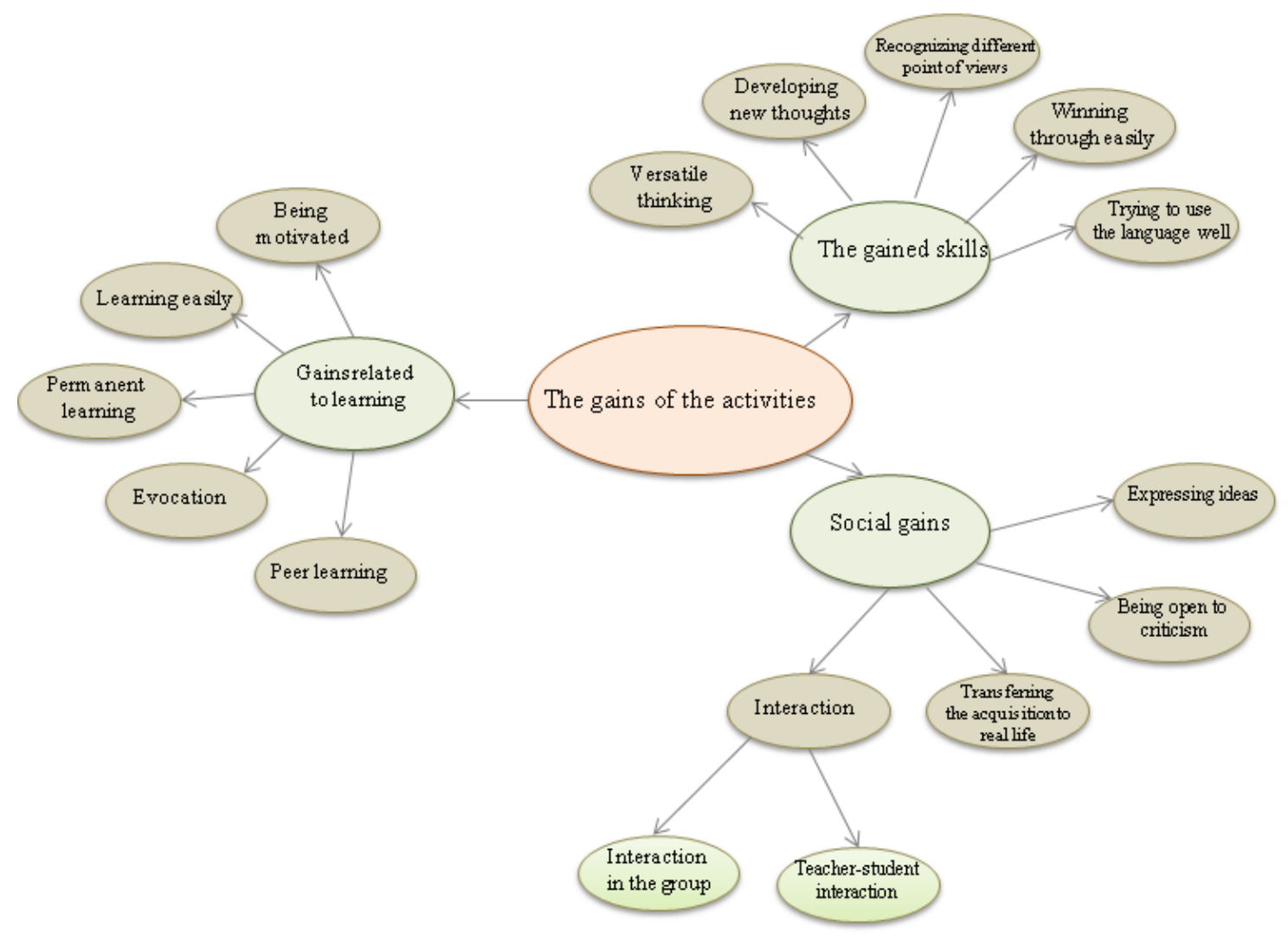

Figure 5. The Gains of the Activities

"Gains related to learning" sub theme is consisted of these codes: "being motivated", "learning easily”, “permanent learning”, “evocation” and "peer learning”.

Kayhan and Caner stated that the learning stories that included the $1^{\text {st }}$ step of 4MAT teaching model helped them be motivated. Caner, Ezgi, and Engin said that the teaching model made them learn easily. Based on this finding, the presented stories not only help increase the attention to the lesson but also make learning easier. Ezgi's statement "particularly the stories 
helped me improve my imagination. I learned the concepts about the topic easily" is a proof that the model has an effect on learning the concepts about the topic.

Caner, Nehir, Yekta, and Engin stated that along with in-studio discussions and presentations as part of 4 MAT teaching model, worksheets, activities and project homework ensured permanent learning. While Seval emphasized that the stories provided permanent learning, Ezgi stated that the stories about the topic provided evocation. This finding is important as it is a proof that the $1^{\text {st }}$ step of 4 MAT teaching model provides integration with tangible life experiences and is effective on remembering the information about the topic. Seval's statement "because I could visualize the activity with similar stories" is a proof of the efficacy of the stories on teaching.

The students' statements such as "I improve quickly when my friends tell me my mistakes”, "I did better in the second time by considering the criticism on my work", "with mutual thoughts we reached accuracy" proves that peer learning environment was created.

"The gained skills" sub theme is consisted of "versatile thinking", "developing new thoughts", "recognizing different point of views", "winning through easily" and "trying to use the language well" codes.

Ezgi stated that sketch studies that were included in the activities helped her gain the ability to think versatile. Seval, Yekta, and Engin emphasized the activities about creating concepts and defining these concepts made them develop new thoughts. Based on student reviews, it can be inferred that activity environment creates a group dynamic and has a positive effect on thinking skills. Kayhan also stated that the criticism during presentations made him recognize different point of views.

As to Ezgi criticism about the created art work and to Caner sketches before art works made them win through easily. Yekta and Engin, on the other hand, stated that the activities had them try to use the language well. Based on these findings, it can be accepted that in-studio 
discussions about student assignments and criticism about the art work of students made them try to use the language well.

"Social gains" sub-theme consists of the following codes: "interaction", "transferring the acquisition to real life", "being open to criticism" and "expressing ideas".

Depending on the findings reached by interaction, Caner and Yekta's ideas reflect that exchange of ideas among the group during the activity proves that there is interaction in the group. Seval thinks that criticizing the artistic works provides interaction. On the other hand, Ezgi's sentence is striking: " I am an introvert person, so I do not find telling my ideas necessary but I gained self-confidence back". This finding can be a proof that activity environment creates a need for students to share their ideas. When teacher-student interaction is considered, Ezgi, Seval, Engin, Yekta, and Caner stated that discussing the questions of presented story, explaining the terms about the subject, criticizing works of art and performance projects allowed interaction with the teacher. According to the finding, activity environment enables students to share their ideas easily with their friends as well as the teacher.

Kayhan, Engin and Caner indicated that workshop discussions had a positive impact on expressing their thoughts in the society, thus acquisition can easily be transferred to real life. However, Caner stated that he had learned how he would reflect his ideas about a work of art from the criticism environment in art studio process. According to the event it can be said that activity environment has a positive impact on evaluating any work of art they have met outside the workshop (art studio). These two sentences prove that activity environment help students to be open to criticism "I learned to be open to criticism" ( by Ezgi) and "We learned being open to criticism outside the art studio" (by Engin). Furthermore, Engin and Seval have stated that activity environment provided an opportunity for students to express their thoughts. 


\section{c) Emotional reactions towards the student' tasks in activities}

Emotional reactions towards the students' tasks in activities consist of these sub-themes: "tasks carried out willingly" and "tasks carried out unwillingly". Activity related sub-themes and codes depending on emotional reactions are presented in Figure 6.

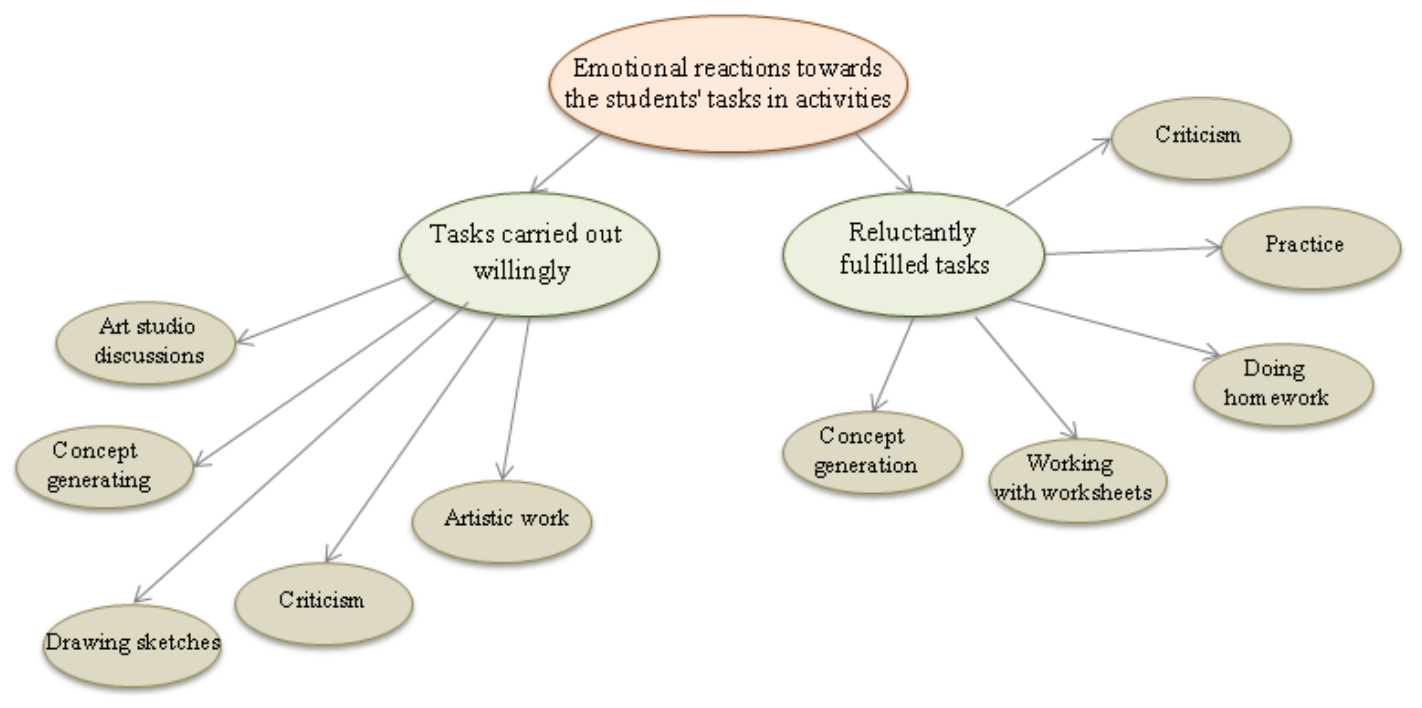

Figure 6. Emotional Reactions towards the Student' Tasks in Activities

Tasks carried out willingly are given with these codes: "art studio discussions", "concept generating", "drawing sketches", "criticism", and "artistic work".

Ezgi stated that she liked studio discussions in presentations, Seval, Yekta, and Caner said that they willingly produced topic related concepts. In addition to them, while Engin and Yekta were in favor of sketch drawing, Melda, Caner, Yekta, and Nehir expressed that they fancied criticizing art works. Furthermore, Yekta and Engin mentioned that another task that they like doing was artistic work.

The diversity of student tasks they like doing during the activity process can be explained with 4MAT teaching cycle that is performed in 8 steps. In other words, students have 
accepted the learning technique that suits best to their own way of learning and fulfilled their tasks more fondly.

Reluctantly fulfilled tasks consist of these codes: "concept generation", "working with worksheets", “doing homework", "practice” and “criticism”.

Yekta and Engin stated that they found concept generating difficult. Ezgi explained that since she had difficulties in writing, she didn't like working with worksheets. Nehir, Seval, and Engin stated that they got bored while they were doing homework. Kayhan stated that he didn't like painting. Also Seval didn't like criticizing art works.

The diversity of student tasks they do not like doing during the activity process can be explained with the 4MAT teaching cycle that is performed in 8 steps. In other words, students found the learning technique difficult that does not suit to their own way of learning. Therefore, it can be said that they did the tasks unwillingly.

\section{d) Aroused feelings due to the activity environment}

Aroused feelings due to the activity environment consist of these sub themes: "feelings that occur in the process" and "expectancies towards activity environment". The codes about these sub themes are shown in Figure 7.

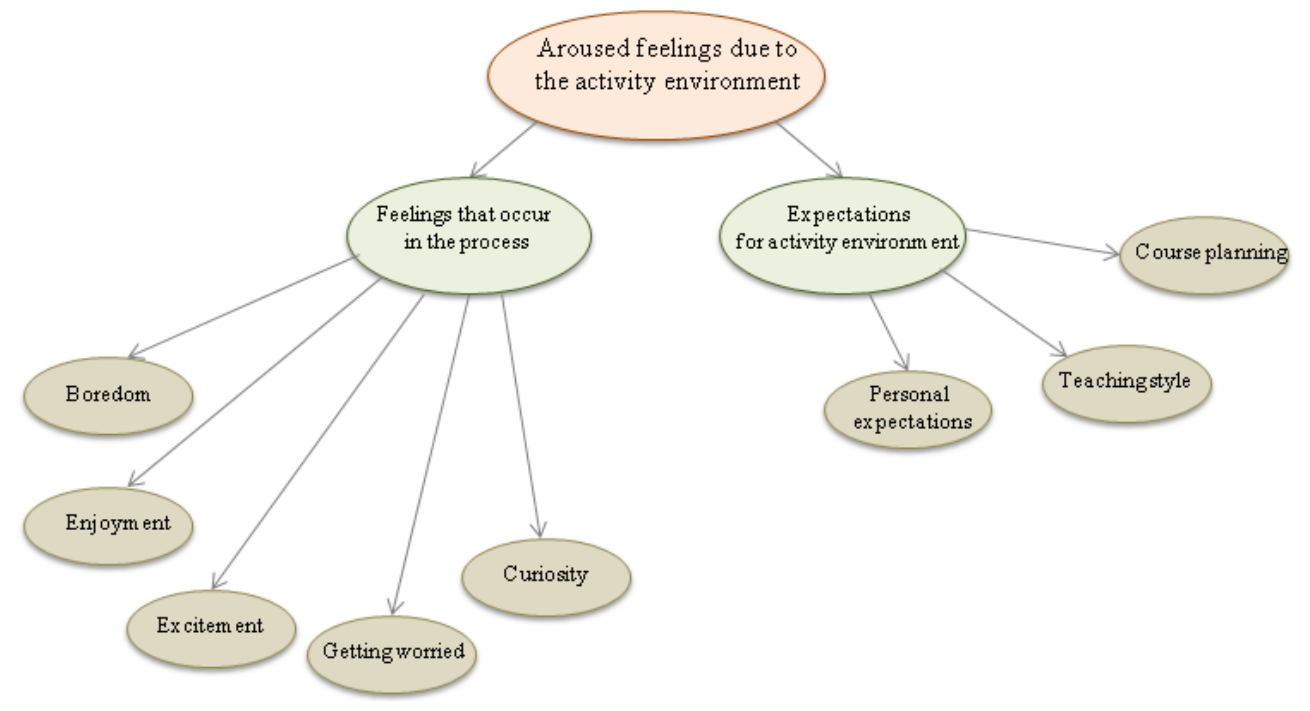

Figure 7. Aroused Feelings Due to the Activity Environment 
Activity process has created some feelings such as "boredom”, “enjoyment", "excitement", "getting worried" and "curiosity".

According to Melda, doing homework during the activity process caused her to get bored and Ezgi stated that topic related stories helped her get pleasure. Kayhan and Ezgi stated that they got excited. Seval explained that activity process caused her to get worried because of not fulfilling her responsibilities. For Nehir, Yekta, and Engin, activity environment had aroused curiosity.

Obtained findings show that Melda only got bored while she was preparing project homework. However, it is thought that such feelings as enjoyment, excitement, worrying, and curiosity can be important factors for the increase in academic achievements.

Expectations for activity environment sub theme was given with these codes: "personal expectations", "teaching style" and "course planning".

Seval and Caner's statements showed that activity environment met their expectations. However their sentences about the course teaching differ in some ways. While Ezgi said that she liked activities but she didn't want to fill in the blanks in worksheets, Melda and Nehir stated that they liked the environment but they didn't want projects. Kayhan indicated he had any negative idea about art critique sessions but he didn't want projects either. Seval added that she didn't like doing homework. Finally, Engin mentioned that his problem was with projects but he had no problem with other activities. Among the group, Yekta had developed an opposing idea. He mentioned that he was aware of the fact that nobody wanted to prepare projects. He added that writing their views on a piece of paper to present the teacher wasn't a difficult task. Also Caner expressed his positive feelings about not changing the teaching method. It shows that he is content with it. 
Achieved results show that lessons conducted with the 4MAT teaching model was efficient and students share the idea that teaching model increases their success. Even Kayhan says that this model should be used in other courses in terms of the continuity of success.

For course planning, Yekta suggests that worksheets are not adequate, and he adds that for the retention of the information diaries that reflect reflection can be kept. Seval's idea is increasing the number of the provided visual examples before the artistic work will be useful.

\section{Conclusion and Recommendation}

Students stated that by using this method, compared with the other two dimensional art studio classes, their responsibilities both inside and outside the art studio had increased. Demirkaya (2003) also emphasizes in his research that this model necessitates a certain responsibility both for the teacher and the student. In addition, it has been concluded that activity environment has provided easy and permanent learning. Aktaş (2011), Blair \& Judah (1990), Wilkerson's (1986) researches support the idea that students have learned easily. As for cognitive learning, students think that model has provided some opportunities such as motivation, association and peer learning. Especially at the eight step of the model, students have stated that the model has contributed to their learning via criticisms for the artworks. Furthermore, Aktaş (2011) indicates that since the model allows active participation of the

students to the lesson, they can learn effectively. From students' views, it has been concluded that students have gained some skills such as multi-dimensional thinking, developing new ideas, reaching the result easily, recognizing different point of views and using language effectively. In addition, they share the idea that activity environment had a positive impact on student-student and student-teacher interaction.

Although students had fulfilled almost all the tasks during the 4MAT teaching model process, their emotional responses differed. In different stages of the process, students experienced 
such feelings as enjoyment, excitement, worrying, wondering, feeling comfortable and boredom. Even though the opportunities provided by the activity environment met student's expectations, almost all of the group members suggested not using performance tasks in other two dimensional art studio classes. For the course planning, students suggested some tasks such as keeping a log for their reflections, increasing the number of visual examples, and the time taken for the criticism sections.

Researches conducted on the basis of learning styles highlights that individuals use the most appropriate learning style for themselves, therefore it is necessary to teach according to the learning styles to increase success (Fuller, 2002, 17; Langa \&Yost, 2007: 47). In this study, 4MAT teaching model, which was designed according to the learning styles and the characteristics of the brain hemisphere, was applied. Consequently, the views of the students can be accepted as an indication that model is successful in meeting the expectations of the course.

Within the framework of student views, in course design teachers and students work together and they can plan some tasks for students that they can fulfill willingly. In addition, it can be suggested that two dimensional art studio classes for upper classes should be designed according to the 4MAT teaching model either.

\section{References}

Açıkgöz Ün, K. (2005). Etkili öğrenme ve öğretme. (6. basım). İzmir: Eğitim Dünyası Yayınları.

Aktaş, İ. (2011) 4MAT modeline dayalı ögretimin yedinci sınıf öğrencilerinin maddenin yapısı ve özellikleri ünitesindeki başarı, motivasyon ve ögrenme stillerine etkisi (Masters' Thesis). Mustafa Kemal Üniversitesi Sosyal Bilimler Enstitüsü, Hatay. 
Appel, C.J. (1991). The effect of the 4MAT system of instruction on academic achievement and attitude in the elementary music classroom (Masters' Thesis). University of Oregon.

Blair, D \& Judah, S.S. (1990). Need a strong fountation for an interdisciplinary program? Try 4MAT. Educational leadership, 48 (2), 37-38.

Buyurgan, S. (2007). Anadolu güzel sanatlar liseleri resim bölümü öğretmenlerinin bölümlerinde uygulanan sanat eğitimi ile ilgili görüşleri, Milli Eğitim, (175), 143-160. Web: http://dhgm.meb.gov.tr/yayimlar/dergiler/Milli_Eğitim_Dergisi/175.pdf

Buyurgan, S. (2000). Anadolu güzel sanatlar liseleri resim bölümü mezunlarının yüksek öğrenimdeki başarı durumları ile ilgili bir değerlendirme, Hacettepe Üniversitesi Ĕ̈itim Bilimleri Dergisi, (19), 32-42.

Web: http://www.efdergi.hacettepe.edu.tr/200019SERAP\%20BUYURGAN.pdf

Caine, R.N. \& Caine, G. (2002). Beyin temelli öğrenme, (Çev. G. Ülgen, O. Turgut, H. Ergen, O.Y. Uğur), (1. basım). Ankara: Nobel Yayın Dağıtım.

Demirkaya, H. (2003). Coğrafya öğretiminde 4MAT öğretim sisteminin lise coğrafya derslerindeki başarl ve tutumlar üzerine etkisi (PhD Thesis). Gazi Üniversitesi Eğitim Bilimleri Enstitüsü, Ankara.

Denison, B \& Kirk, R. (1990). Do, review, apply: A simple guide to experimental learning. Oxford: Basil Blackwell.

Dikkartın, F.T. (2006). Geometri ögretiminde 4MAT öğretim modelinin ögrrenci başarısı ve tutumlarl üzerine etkisi (Masters' Thesis). Balıkesir Üniversitesi Fen Bilimleri Enstitüsü, Balıkesir.

Duman, B. (2007). Neden beyin temelli öğrenme?, (1. basım). Ankara: Pagema Yayıncılık.

Ekici, G. (2003). Öğrenme sitiline dayalı ögrretim ve biyoloji dersi ögrretimine yönelik ders planı örnekleri. Ankara: Gazi Kitabevi. 
Erden, M. \& Altun, S. (2006). Öğrenme stilleri. (1. basım) İstanbul: Morpa Kültür Yayınları.

Ergin, S. (2011). Fizik ĕgitiminde 4MAT öğretim yönteminin farklı öğrenme stillerine sahip lise öğrencilerinin iş, güç ve enerji konusundaki başarısına etkisi (PhD Thesis). Gazi Üniversitesi Eğitim Bilimleri Enstitüsü, Ankara.

Fuller, C. (2002). Ben farklıyım çocuğunuzun öğrenme tarzını keşfedin. (Çev. G. Öztürk). (1. basım). İstanbul: Selis Kitaplar.

Jackson, P. R. (2001). The effects of teaching methods and 4MAT learning styles on community college students' achievements, attitudes and retention in introductory microbiology (PhD Thesis). Lynn University, USA.

Johnson, P. A. (2005). A short guide to action research. (Second edition). Pearson Education, Inc.

Keefe, J. W. \& Ferrell, B.G. (1990). Developing a defensible learning style paradigm. Educational Leadership, 48 (1), 57-61.

Kırışoğlu, O.T. (2005). Sanatta eğitim görmek öğrenmek yaratmak, (3. basım) Ankara: Pagema Yayınc1lı.

Kolb, D. A. (1984). Experiential learning experiencies as the source of learning and development. New Jersey: Prentice Hall.

Kuş, E. (2003). Nicel- nitel araştırma teknikleri. sosyal bilimlerde araştırma teknikleri nicel mi? Nitel mi?. Ankara: Anı Yayıncıl1k.

Langa, M.A. \& Yost, J.L. (2007). Curriculum mapping for differentiated instruction, $k-8$. California: A sage Puplications Company.

McCarthy, B. (1982). Improving staff development through CBAM and 4MAT, Educational Leadeship, 40 (1), 20-25.

McCarthy, B. (1987). The 4MAT system: teaching to learning styles with right / left mode techniques. Barrington:Excel Inc. 
Anadolu Journal of Educational Sciences International, Art Education Special Issue, November 2015

McCarthy, B. (1997). A tale of four learners, Educational Leadeship, 54 (6), 46-51.

McCarthy, B. (2000). About teaching 4MAT in the classroom. Illionois: About Learning Inc.

McCarthy, B. \& McCarthy, D. (2006). Teaching around the 4MATcycle:Desinging instruction for divers learning styles, California: Corwin Pres.

Mills, G.E. (2007). Action research: A guide for the teacher researcher. (Third edition). New Jersey: Pearson Education, Inc.

Mutlu, M. (2004). Illköğretim 8. Sinıf fen bilgisi dersinde fotosentez- hücresel solunum konusunun 4MAT ögretim modeli kullanılarak öğretilmesinin öğrenci tutum ve başarısı üzerine etkisi (PhD Thesis). Gazi Üniversitesi Eğitim Bilimleri Enstitüsü, Ankara.

O'Banion, T. (1997). A learning collage for the 21st century. Phoneix: American Council on Education Oryx Press.

Özsoy, V. (2003). Görsel sanatlar eğitimi. (1. basım) Ankara: Gündüz Eğitim ve Yayıncılık.

Öztürk, Z. (2007). Öğrenme stilleri ve 4MAT modeline dayalı öğretimin lise tarih derslerindeki ögrrenci başarısına etkisi (Masters’ Thesis). Gazi Üniversitesi Eğitim Bilimleri Enstitüsü, Ankara.

Paxcia-Bibbins, N. (1993). The effects of the 4MAT system of instruction on the attitudes and achievement of elemantry children in music listening lesson (PhD Thesis). Ball State University, Muncie, Indiana.

Peker, M. (2003). Öğrenme stilleri ve 4MAT yönteminin ögrencilerin matematik tutum ve başarllarına etkisi (PhD Thesis). Gazi Üniversitesi Eğitim Bilimleri Enstitüsü, Ankara.

San, İ. (2004). Sanat ve eğitim yaratıcılık temel sanat kuramları sanat eleştirisi yaklaşımları. (3. basım). Ankara: Ütopya Yayınevi. 
Stinespring, J. \& Kennedy, L. (1993). Using the 4MAT learning style inventory in the art classroom, Paper presented at 32nd Annual Conference of the Texas Art Education Association, Texas.

Stringer, E.T. (2008). Action research. (Second edition). USA: Pearson Education NJ

Tatar, E. (2006). İkili işlem kavramı ile ilgili öğrenme güçlüklerinin belirlenmesi ve 4MAT ögretim yönteminin başarıya etkisi, (PhD Thesis). Atatürk Üniversitesi Fen Bilimleri Enstitüsü, Erzurum.

Ursin, V. D. (1995). Effects of the 4MAT system of instruction on achievement, products and attitudes toward science of ninth grade students (PhD Thesis). The University of Connecticut, USA.

Uysal, F. (2009). Illköğretim 6. Sınıf matematik dersi “kesirler” konusunun öğretiminde 4MAT öğrenme stili modelinin öğrenci başarısına etkisi (Masters' Thesis). Gazi Üniversitesi Eğitim Bilimleri Enstitüsü, Ankara.

Wilkerson, R.M. (1986). An evaluation of the effects of the 4MAT system of instruction academic achievement and retention of learning (hemisphericity) (PhD Thesis). The University of North Carolina at Capel Hill, USA.

Wilkerson, R.M. \& White, K.P. (1988). Effects of the 4MAT system of instruction on student's achievement, retention and attitudes. The Elementary School Journal, 88(4), $357-368$.

Yavuz, S. (2010). İki boyutlu sanat atölye dersinde yapılandırmacı yaklaşıma dayalı öğretim uygulamalarına ilişkin ögretmen ve ögrenci görüşleri (Ordu güzel sanatlar ve spor lisesi örneği) (Masters' Thesis). Anadolu Üniversitesi Eğitim Bilimleri Enstitüsü, Eskişehir.

Yıldırım, A \& Şimşek, H. (2006). Sosyal bilimlerde nitel araştırma yöntemleri, (6. basım). Ankara: Seçkin Yayıncılı. 